\title{
La Mothe Le Vayer's Interest in Names
}

\author{
JOHN VAN EERDE
}

F

RANÇOIS DE LA MOTHE LE VAYER is known to students of seventeenth century French literature as a sceptic and a scholar, who, born in 1588, belonged to a distinguished circle of learned men, including Diodati, Gassendi, and Naudé. A follower of Baranzani, who introduced him to many of the implications of the Copernican theory, Le Vayer directed his mind to a multiplicity of subjects. One of these is onomatology. This article will concern itself with the various aspects of that topic found in the 5700 pages of the 1669 edition of the CEuvres complètes.

The comments of Le Vayer upon the Nominalist-Scotist quarrels are a typical indication of his philosophical interest in names. He remarks that thinkers like Ockham and Roscellinus protested against the Scotist view that Universals are real things, that actually subsist, holding instead that Universals are pure terms or names invented at one's pleasure. ${ }^{1}$ Elsewhere Le Vayer resists going so far as the Stoics, who would call each thing by its name, but warns against the exaggerated avoidance of exact terms. ${ }^{2}$ In yet another portion of his writings Le Vayer raises the whole question as to the origin of names. Do they come from the pure instinct of Nature or from men's fantasy? Plato holds for the natural origin; Socrates accepts both possibilities. Genesis shows Adam naming things as he liked, while Diodorus the Sicilian claims that men were at first inarticulate and became articulate only through the gesture that accompanied the word as they pointed out what they were talking about. ${ }^{3}$

In a chapter of Des Petits Traitez en forme de lettres, entitled "Des Noms," Le Vayer sketches the history of names in religion and

1 La Mothe Le Vayer, Homilies académiques, 1lème, in Euvres (Paris, 1669), $\mathrm{XIV}, 146$. Subsequent references are to this edition.

2 Le Vayer, De L'Eloquence française, in Euvres, IV, 17.

${ }^{3}$ Le Vayer, Des Petits Traitez en forme de lettres, in Euvres, X, Lettre XXXIII. 
philosophy. ${ }^{4}$ He points out again that in Genesis Adam gives a name to everything created. Plato, he continues, sees names as the instruments proper for discerning the substance of things. Epicurus, Le Vayer says, thinks of the first names ever used as the effects men have imagined to emanate from each material object. Nigidius, like Plato, considers names to stem from Reason and calls them natural as opposed to positive and arbitrary. For Pythagoras names are the result of extreme and sovereign wisdom. Aristotle and the Stoics seek the fundamental truth of things in names. In the sixth chapter of Exodus God has a name and reveals it to Moses. And Eusebius shows in Chapter 6, Book XI of the Evangelical Preparation, that God's name is formed by the seven vowels of the four elements of grammar. ${ }^{5}$

Le Vayer, typical of his century, leans heavily upon such writers of the past as Pliny, Solinus, Diodorus, and Homer, in whom he finds examples of certain animals responding to particular names. Thus dolphins answer to Simon, goats to Jeanne, and donkeys to Martin. Whereas in Libya children have been given the names of monkeys, recently history has attested to a monkey named Robert, a lamb Robin, a crow Colas, a jay Richard, a magpie Margot, blackbirds and starlings called Little Sampson, and a parrot Little Peter.

From history and literature further materials for Le Vayer's chapter are gathered. Thus Valerius Soranus was executed for revealing Rome's secret name (Valentium).$^{6}$ The Chinese changed their kingdom's name with each change of dynasty. In Homer, the gods and men call a certain column by different names. Just so does the Xanthus River of men become the Scamander of the gods. In Iliad 14. 291 the gods call a certain night-bird khalkis, while men call it kymindis.

4 Le Vayer, op.cit., Lettre XVIII.

5 The reference is obviously to Yahweh and is part of a long discussion on sacred names. See Eusebii Caesariensis Opera (Leipzig, 1867), II, 16. In another work Eusebius discusses the name of Jesus. See his Ecclesiastical History, tr. Rev. C. F. Crusé (Boston, 1836), bk. 1, ch. 3, pp. 21-25.

6 The unreliable chronicle of Cuma refers to Valentia as an early name of Rome. The name is commented upon by H. F. Pelham, Outline of Roman History (New York, 1901), 261 : "To the colonies must be added not only the fora, established by Roman magistrates . . . but the numerous settlements of Roman citizens up and down the country, with their characteristically euphemistic names, Industria, Faventia, Pollentia, Fidentia, Valentia, Florentia." 
Papal history makes its contribution to the subject as Le: Vayer inquires into the origin of the Pontiff's assumption of a new name upon his election. Plotinus is cited as claiming that Sergius II started the custom in order to avoid being called "A Pig's Snout." Baronius traces the tradition to the humility of Sergius III in eschewing Peter, his baptismal name. Onuphrius would carry the matter back to John XII (or XIII, depending on how you count the Johns), who wished to dissociate himself from the too aristocratic name of Vespasian. Finally Le Vayer cites an opinion that the custom is an imitation of St. Peter, who was called Simon before Jesus gave him his nickname of Cephas.

The similar adoption of a new name is of course evident outside of the Papacy. In Ethiopia Atani-Tingil assumed the name of David on coming to the throne, and in Rome Diocletian had been Diocles before becoming Emperor. In Book IV of Kings Necho names Kliakim Joachim when putting him on the throne. Just so did Nebuchadnezzar change the name of Mathaniah to Zedekiah on making the latter king.

Sometimes an individual's name is changed more than once. Homer is reported to have been called Melesigenes and Tigranes before his enduring name became his. Moses, according to Clement the Alexandrian, was called Joachim until he was three months old and had a third name, Melchi. Le Vayer notes that the Japanese and Chinese, like some Christians, change their names as many as three times. He pursues the subject in another major chapter devoted to names in a later volume. ${ }^{7} \mathrm{He}$ discusses people who have wanted to change their names, alluding to the wrath visited upon Christians by Pope Paul II for choosing pagan names.

Le Vayer himself accepts a nasty or pleasant sound or association as a legitimate reason for the changing of a name. That reason is illustrated by such a name as Reuchlin, meaning "manure," and also called Capnio on occasion. Reuchlin himself gave Melanchthon his name, the Greek translation of Schwartzerd (Black Earth). Other changes of name listed by Le Vayer exemplify the Renaissance indulgence in latinization and include the altering of Martin Bucer to Aretius Felinus, Gherardus Gherardi to Erasmus. He also mentions Dr. Sammalitius ('Without Malice') being changed to Akakia, and

7 Le Vayer, Des Petits Traitez, in EEuvres, XII, Lettre CXLI. 
Janus Nicius Erythraeus, who addressed a dialogue on history to Le Vayer, to Ianne Vittorio de Rossi, as he was known in Rome.

The psychological reason behind a change of name is obviously what has interested Le Vayer in many instances. Thus he finds Aristotle calling his favorite disciple Theophrastus rather than Tyrtanus. The Romans were so affected psychologically by names that when raising troops they always tried to make sure the first recruit bore a name indicating a good augury. The name Regillianus was liked so much that the bearer became Emperor wholly on the strength of it, says Le Vayer. Jovian sounded so like Julian of the then cherished memory that he was chosen Emperor. In more modern times the French ambassador chose Alfonso IX's ugly daughter to wed the French king rather than her sister whose name, Urraca, was considered ugly. ${ }^{8}$ Another type of rejection in Spain concerned a priest named Martin Luther, who was refused a favor by Philip II for the obvious reason. The attachment of a moral and social connotation to names is a universal phenomenon. Thus Abel and Benjamin have been associated with mourning and sadness in Hebrew, as have been Tantalus and Pentheus in Greek. In France the name Tristan has been given to princes born in some notable affliction. Egerius was the traditional name of beggars in Rome. The Egyptians considered Cheops and Cephrenes to have such unhappy associations that they said the shepherd Philiton built the Pyramids. It has been thought ominous that all the Caius Caesars perished by the sword. The Janes, Queens of Naples, and the Jameses, Kings of Scotland, were also unfortunate. Pope Paul II was advised to avoid the name Formosus because of Pope Formosus having been exhumed by Stephen VI. The Irish avoid giving a child the name of a living relative for fear of shortening the latter's life, and the Hurons seem to do likewise. ${ }^{9}$

Chance may associate a name with an unhappy historical event as in the War of Granada in 1566. A general called to a soldier named Santiago. Others took it for the signal to attack, and the battle was

8 Amy Kelly, whose source is Don Pedro Niño, Sumario de los Reyes de España, in Colección de las crónicas de Castilla (Madrid, 1782), 3, pt. 1, recounts the diplomacy involved in this episode and states that both Urraca and her sister, Blanche, were beautiful. See Amy Kelly, Eleanor of Aquitaine (Cambridge, Mass. 1950), 359.

${ }^{9}$ Le Vayer, Des Petits Traitez, in Euvres, X, Lettre XXXIII. 
lost. ${ }^{10}$ In a happier coincidence Tamerlane is supposed to have named his son and a newly constructed town Sarachi, since his son was born and the town finished as he was gaining an important check in chess, known as Sarache in Arabic. Other onomastic connotations connected with history are ones such as Nero, which meant '(brave) man' in the Sabine tongue originally, and Bajazet, the name of sultans, used also as a pig's name, which was given to the animal out of scorn for the Turks.

Le Vayer also mentions the exclusiveness of certain names. Athens forbade men of low estate to call themselves Harmodius or Aristogeiton. In Rome Claudius forbade foreigners to take the names of Roman nobles. And in Le Vayer's day, Portuguese travelers apparently assumed illustrious names once they crossed the Equator en route to India. ${ }^{11}$

Le Vayer also comments on the lengthening and shortening of names. ${ }^{12} \mathrm{He}$ cites God's making Abram into Abraham and Simon, of whom Lucian speaks, changing his own name to Simonides on becoming rich. And there is Bruna, the wife of Sigebert of Austrasia, who became Queen Brunehault or Bruenchildis (Brunhilda). Occasionally a syllable may be added or dropped out by chance as in Sybilla which became Sylla.

The above examples have involved various substitutions of one name for another. There are, however, cases - as Le Vayer notes in which people receive no name at all, such as the Atlantes in Libya and the girls in China, the latter being designated simply by their order of birth. The lack of a name may also be indicated by designating an individual as Anthropos (so says Aristotle, Ethics 7.6) or simply No Man, None, which Ulysses wanted to be called in order to deceive Polyphemus.

Where names are given, there are differences in custom as to the age at which the name is bestowed. Civilizations that have given names at a later age than the Christians include the Roman (boys being named at nine, girls at eight) and the Greek, in which children were named at seven.

10 Le Vayer, Des Petits Traitez, in Euvres, XII, Lettre CXLI. Santiago of course means Saint James. San Diego is a variant.

11 Le Vayer, Des Petits Traitez, in Euvres, X, Lettre XXXIII.

12 Le Vayer, op.cit. 
Le Vayer closes his chapter "Des Noms". with a long list of princes' names attached to sovereignty. For the reader's convenience these are presented here alphabetically (something which Le Vayer does not do) with their geo-location:

\begin{tabular}{|c|c|c|c|}
\hline Abimelech & Palestine & Cypselides & Corinth \\
\hline Aladin & Iconium & Ignatius & Jacobites \\
\hline Alevades & Thessaly & & (Patriarch of) \\
\hline Alexander & $\begin{array}{l}\text { Balaxian } \\
\text { (territory } \\
\text { mentioned by } \\
\text { Marco Polo) }\end{array}$ & $\begin{array}{l}\text { Melich (David) } \\
\text { Miramamolin } \\
\text { Mithridates } \\
\text { Nicomedes }\end{array}$ & $\begin{array}{l}\text { Georgia } \\
\text { Africa } \\
\text { Pontus } \\
\text { Bithynia }\end{array}$ \\
\hline Arsaces & Parthia & Palibotres & India \\
\hline Artaxerxes & Persia & Peter & Maronites \\
\hline Augustus & Rome & & (Patriarch of) \\
\hline Candace & $\begin{array}{l}\text { Ethiopia } \\
\text { (Queens of) }\end{array}$ & $\begin{array}{l}\text { Sylvia } \\
\text { Taxiles }\end{array}$ & $\begin{array}{l}\text { Rome } \\
\text { India }\end{array}$ \\
\hline Chagan & $\begin{array}{c}\text { Huns and } \\
\text { Bavaria }\end{array}$ & $\begin{array}{l}\text { Tygranes } \\
\text { Zulcarnes }\end{array}$ & $\begin{array}{l}\text { Assyria } \\
\text { Balaxian }\end{array}$ \\
\hline Crales & Serbia & & \\
\hline
\end{tabular}

Le Vayer adds a shorter list of titles that have traditionally been bestowed upon the successor to the throne in certain places:

\begin{tabular}{|c|c|c|}
\hline $\begin{array}{l}\text { Prince of the } \\
\text { Asturias }\end{array}$ & Castile & $\begin{array}{l}\text { Duke of } \\
\text { Barcellos } \\
\text { Prince of Brazil }\end{array}$ \\
\hline
\end{tabular}

(Le Vayer says that the latter title has been described to him as "d'une Pragmatique tout nouvelle"):

Duke of

Calabria

Count of

Charolles

The Dauphin

Duke of Girona
Duke of

Montblanc Catalonia

Duke of Rothesay Scotland

Prince of Viane Navarre

Prince of Wales England

Another chapter in the same work by Le Vayer is entitled "Des Epithètes."13 Here he reminds the reader that philosophers, especially the Stoics, consider names as serving to identify the very substance of things. He further states that, since epithets are a kind of second name, invented to designate more accurately that which

${ }^{13}$ Le Vayer, op.cit., Lettre XVIII. 
already has a name, they too must be important. He notes that professors and theologians have been particularly prone to epithets.

He gives a long list, which here also is arranged alphabetically for the reader's convenience:

\begin{tabular}{|c|c|c|c|}
\hline NAME & EPITHET & NAME & EPITHET \\
\hline Abelard & $\begin{array}{l}\text { The Dialecti- } \\
\text { cian }\end{array}$ & $\begin{array}{l}\text { Hippocrates } \\
\text { John of Oxford }\end{array}$ & Divius \\
\hline $\begin{array}{l}\text { Agrianus } \\
\text { (Michael) }\end{array}$ & $\begin{array}{l}\text { The Unknown } \\
\text { Doctor }\end{array}$ & $\begin{array}{l}\text { or of Bacon- } \\
\text { thorpe }\end{array}$ & Dr. Resolutus \\
\hline Alanus & $\begin{array}{l}\text { The Universal } \\
\text { Doctor }\end{array}$ & Lescot & $\begin{array}{l}\text { The Subtle } \\
\text { Doctor }\end{array}$ \\
\hline $\begin{array}{l}\text { Albert, Bishop } \\
\text { of Ratisbon }\end{array}$ & The Great & $\begin{array}{c}\text { Lombard } \\
\text { (Peter) }\end{array}$ & $\begin{array}{l}\text { The Master } \\
\text { of Sentences }\end{array}$ \\
\hline $\begin{array}{l}\text { Alexander the } \\
\text { Aphrodisian }\end{array}$ & The Interpreter & $\begin{array}{l}\text { Lully } \\
\text { (Raymond) }\end{array}$ & $\begin{array}{l}\text { The Enlighten- } \\
\text { ed Doctor }\end{array}$ \\
\hline $\begin{array}{l}\text { Antiochus } \\
\text { Archelaus (So- }\end{array}$ & God & Martinus & $\begin{array}{l}\text { Martinus contra } \\
\text { communem }\end{array}$ \\
\hline $\begin{array}{l}\text { Archelaus (So- } \\
\text { crates' tutor); } \\
\text { also Strato of }\end{array}$ & & Ockham & $\begin{array}{l}\text { Venerabilis } \\
\text { Inceptor }\end{array}$ \\
\hline $\begin{array}{l}\text { Lampsacus } \\
\text { (Theophrastus' } \\
\text { disciple) }\end{array}$ & The Physician & Origen & $\begin{array}{l}\text { The Syntactic } \\
\text { or the Compo- } \\
\text { ser }\end{array}$ \\
\hline Aristides & The Just & Petrus of Apono & The Conciliator \\
\hline Aristotle & $\begin{array}{l}\text { The Genius } \\
\text { of Nature }\end{array}$ & Philo & $\begin{array}{l}\text { The Circum- } \\
\text { cized Plato }\end{array}$ \\
\hline Averroes & $\begin{array}{l}\text { The Commen- } \\
\text { tator }\end{array}$ & $\begin{array}{l}\text { Phocion } \\
\text { Plato }\end{array}$ & $\begin{array}{l}\text { The Good } \\
\text { Divius and }\end{array}$ \\
\hline $\begin{array}{l}\text { Dr. Campegius, } \\
\text { also Dr. Dedonis }\end{array}$ & The Aggregator & & $\begin{array}{l}\text { The Athenian } \\
\text { Moses }\end{array}$ \\
\hline Domus (Thomas) & Dr. Veritatis & Rabbi Moses & Dr.Perplexorum \\
\hline Durandus & The Speculator & Rafis & Experimentator \\
\hline Gerson & $\begin{array}{l}\text { The Very Chris- } \\
\text { tian Doctor }\end{array}$ & Ripa (Lucas) & $\begin{array}{l}\text { Magister } \\
\text { Syllabarum }\end{array}$ \\
\hline $\begin{array}{l}\text { Grammaticus } \\
\text { (Johannes) }\end{array}$ & $\begin{array}{l}\text { The Industri- } \\
\text { ous or Philo- } \\
\text { pone }\end{array}$ & $\begin{array}{l}\text { St. Bonaventure, } \\
\text { also St. Hilary } \\
\text { St. Thomas }\end{array}$ & $\begin{array}{l}\text { The Seraphic } \\
\text { Doctor } \\
\text { The Angelic }\end{array}$ \\
\hline $\begin{array}{l}\text { Gregory of } \\
\text { Nazianzus }\end{array}$ & The Theologian & Socrates & $\begin{array}{l}\text { Doctor } \\
\text { The Wise }\end{array}$ \\
\hline $\begin{array}{l}\text { Henry of } \\
\text { Ghent }\end{array}$ & $\begin{array}{l}\text { The Solemn } \\
\text { Doctor }\end{array}$ & $\begin{array}{l}\text { Suiseth } \\
\text { (Richard) }\end{array}$ & The Calculator \\
\hline
\end{tabular}


Another phase of the epithet treated by Le Vayer concerns the slight change of a name for the purpose of effect. Thus, because of his follies Epiphanes was called Epimanes. Ptolemy Euergetes, which means 'The Beneficent,' became Ptolemy Cakergetes, meaning 'The Malevolent.' Other such changes include Plato to Sato ("The Well-Jointed"), Democritus to Leroclitus or Lemocritus, Chrysippus to Chesippus and Tiberius to Biberius. A certain military commander named Belle-garde lost a fort to the enemy and was thereafter called Malle-garde by the Duke of Savoy. The Romans renamed the town Maleventum, Beneventum. Because of the evil presage of Epidamnus, that name was changed to Dyrrachium. An Arabian town named Siene 'ugly' became Asna 'beautiful.' Lycon's name was changed to Glycon to indicate his soft speech. Justinian I's wife, Lupicana, became Euphemia to avoid all suggestion of resemblance to her own name. Sometimes there is a type of irony (antiphrasis) in the epithet bestowed as in the case of the three Ptolemies of Egypt, called Philadelphus, Philometor, and Philopator, respectively, although they had killed a brother, a mother, and a father.

Le Vayer tells us that he has found more material on his subject in Pliny and Macrobius. In the Natural History (Book XI) it is shown that names like Strabo, Coclites, Scaures, and Vares were given because of some bodily mark; that the Stolons and Frondites came from trees, and that the persons named Piso, Fabius, Lentulus, and $C$ icero received their names from the crops they grew.

Recent history, says our author, shows kings and princes among those receiving some very interesting names. He mentions Foulques d'Anjou, known as Gray-Beard, and Raymond of Barcelona, called Stuffing-Head. King Alfonso of Castile carried generosity to the point where he was referred to as Pierced Hand, and King Ferdinand was El Emplezado (One called before the court.). Garcias Sanctius was known as The Trembler just as a Roman Consul spoken of by Livy was called Quintus Martinus Tremulus, and a certain informer Timidius. Two notable Roman epithets based on moral qualities are Ovicula (Little Sheep) by which the mild Quintus Fabius Maximus was known, and Corculum (Little Heart), the name given to Publius Scipio Nasica. Finally the Spaniard Paulus was so good at intrigue in the Court of Constantine that he was called Catena (Chain). 
The subject of epithets furnishes some French and foreign parallels. Caesar's Diviaticus relates semantically to French, Richardière; Greek Lycisca is French Louvet (wolf-color); Roman Pecuniola corresponds to French Argenton or Argenteau (having to do with silver or money).

In his work, La Géographie du prince, Le Vayer discusses the names of cities and countries. ${ }^{\mathbf{1 4}} \mathrm{He}$ remarks that under the Turks Athens was called Setina; Thebes, Stives; and Sparta, Misithra. Poland (he explains) derives its name from pole 'country,' a reference to Poland's flat countryside. It is also pointed out that Königsberg is sometimes known by the French translation of the word, Royaumont or Montroyal..$^{15}$ In another work, Le Vayer's chapter, "Des Villes remarquables," continues this subject.16 Here we are again told that Rome's secret name was Valentium and that Athens was named for the plurality of its women. ${ }^{17}$ Menander is the authority invoked to claim for Athens the names of Carthinia, Cecropia, Acte, and Attica. Stating that Jerusalem has had the greatest number of names, Le Vayer quotes the couplet:

Solyma, Lusa, Bethel, Ierosolyma, Iebus, Elia, Urbs sacra, Ierusalem dicitur, atque salem.

According to Le Vayer, Samaria is said to be named for the Samarites, guards whom Salmanasser placed over a colony of Assyrians. Alep, the first town in a certain region, was so named because aleph is the first letter in Hebrew and Arabic. Susa is reported to have been called Lis because of its beauty. Istanbul is explained as a corruption of the word "Constantinople," or as originating in three words uttered by Greeks en route to that city, or from "Istamboul," meaning 'the abundance of the faithful.' " Cairo is suggested to have come either from Arabic Chaira, meaning 'hatching chicken,' or from Cahar, meaning 'to conquer,' or, finally, from Cairoam,

14 Le Vayer, La Géographie du Prince, in Euvres, VI, 65.

15 Le Vayer, op.cit., 75-76.

16 Le Vayer, Des Petits Traitez, in Euvres, XI, Lettre XCI.

17 Despite many such theories regarding the name, Athens is now generally thought to be derived from the patron goddess, Athene.

17a The Turkish name Istanbul for Constantinople is of course from Gr. stim-bobli 'in or at the City' (Póli in mod. Greek 'Con/ple'). See D. J. Georgacas, "The Names of Constantinople," Trans. of the Amer. Philolog. Assoc. 78 (1947), 366f. [D. J. G., Ed.] 
meaning 'council' or 'assembly.' Cairo has also been called both Babylon and Bagdad, the name of a hermit who lived near the city. Carthage is 'the city of gardens'; and Fez means 'gold,' that metal having been found when Moulay Idris established the city. Tripoli is said to refer to the three towns located within it (Tyre, Sidon, and Aradus). In Sicily Tricala or Triocala (where modern Caltabellotta) is traced to its having three remarkable things, commemorated by Greek words which have been transliterated. Famagusta for Greek Ammochostos is paretymologically traced to Fama Augusti 'Augustus' Renown,' a reference to Augustus' defeat of Antony there. Samos is said to have come from the Greek name for lofty things. Le Vayer also discusses the French suffix -dun on names, as in Chateaudun, pointing out that it means 'high place' in Old Gaulois. Thus Lugdunum meant 'Mount of Crows' if the whole word was Gallic and 'Mount of Light' if the first syllable was Latin (lux). Le Vayer makes a similar claim of geographical connotation for towns called Verrues, earlier Verrucas. The Thracian ending -brie (Greek -bria) is cited as the equivalent of Greek pólis 'city.' The name Terouenne is explained as Terra vana (badly situated territory). In the Far East, Le Vayer speaks of Quinsai, meaning 'City of Heaven,' and Singiù, signifying 'City of Health.' Both Calamina and Meliapur mean 'City of Peacocks,' many of which are found in those places. Malacca means 'Exile,' a name indicating a most suitable place for happy banishment.

Many types of discussion are pursued by Le Vayer on the subject of names. For instance, as a figure of speech he brings up antonomasia, that is, the use of a name belonging to several to designate one. His examples are the Apostle for St. Paul, the Greek Poet for Homer, and the Latin Orator for Cicero. ${ }^{18}$ In this same chapter he notes how names may be played upon to produce different meanings. He cites Cicero's play on Varro whom he called Verrem nequam (Evil Swine). He mentions a similar technique used in the Philippics against Marc Antony.

Le Vayer's interest in names even extends to famous horses of history. ${ }^{19}$ Thus he writes of Pherenicus (Bearer of Victory), King Hiero's horse at the Olympic Games, where there also starred

${ }_{18}$ Le Vayer, La Rhétorique du Prince, in Euvres, VI, 191.

19 Le Vayer, Des Petits Traitez, in CEuvres, X, Lettre XLI. 
Pertinax, the Emperor Commodus' steed. In Juvenal's Satire VIII, Le Vayer finds Corintha and Hirpin mentioned as famous horses of their time. Hadrian's hunting-horse, we are told, was named Boristhenes. Selim owned Carabula (Black Cloud), and Emperor Varus named a crystal vase after his horse, Volucer.

Plant life is another subject which evokes comment on Le Vayer's part with regard to names. He notes that a certain sensitive plant in the "Jardin Royal" is one that Pliny calls Aeschynomenen and which moderns call Herbe pudique or $H$. honteuse or $H$. vergogneuse (The Modest Plant). ${ }^{20}$ Le Vayer also mentions a plant named by a Dr. Menardes of Seville, the Bajatene or Sevadilla, a type of barley that wilts or revives according to how much it is touched.

In another major chapter on names Le Vayer speaks of the weight a name carries through the ages..$^{21}$ Surely, he claims, great names of history and fable evoke universal desire to emulate the famous bearer; for example, Alexander, Caesar, Pompey, and Hercules. ${ }^{22}$ The Spaniards say, "A que buen nombre, no presumo yo que sera menos el hombre" (Who has a good name, I do not presume will be less of a man). Le Vayer cites Dio Cassius to the effect that Caesar took a soldier named Scipio to Africa because the Scipios were reputed always to win there.

We have already seen instances of individuals who have wanted to change their offensive names. Le Vayer also cites whole groups with a similar desire. Turkish Moslems have preferred being called Musulmans (Believers or Orthodox) to Turks (The Banished). Some Jews might be sensitive to the meaning of the name Hebrew, which suggests 'Passer-by' or 'Stranger.' The Pelasgi bore their somewhat flighty name meaning 'Vagabonds' or 'Wanderers.'22a Groups have sometimes been unable to rid themselves of an unpleasant name. The Locrians could not escape the name Ozol, meaning 'Stinking': it was thought to be derived from Nessus or from the serpent,

20 Le Vayer quotes Pliny's explanation for the name: “. . . quoniam appropinquante manu folia controheret" (Since, on the approach of the hand, the leaf will draw itself in). Le Vayer, op. cit., Lettre L.

${ }^{21}$ Le Vayer, Des Petits Traitez, in Wuvres XII, Lettre CXLI.

22 Hercules, Le Vayer notes, was first named Alcaeus and was first given a name by Virtue, through the mouth of Pythia, according to Apollodorus.

22a This is hardly the case concerning the origin of the name; cf. now Fritz Lochner-Hüttenbach, Die Pelasger (Vienna, 1960), 143-146. [D. J. G., Ed.] 
Python, or from the goatskin or sheepskin worn by the Ozolian Locrians. Le Vayer descries a modern parallel in the Jesuits' name of Robes Noires (Black Robes) in Canada, similar to the Ancients' Melanchlaeni.

Examples of individuals trying to avoid or change their names were noted above. Sometimes there has been an official prohibition against taking a name. The family of Manlius Capitolinus, after his execution as a traitor, decided against further use of his name, Marcus. The Greeks suppressed the name of the man who, to perpetuate his name, burned the temple of Diana at Ephesus. Ruthven in Scotland and Ravaillac in France are traitors' names also suffering from general disapprobation.

Furthermore, Le Vayer gives evidence of a scholar's interest in names. It is obvious that the study of pertinent words enabled him to make up lists of names comprising chapters or major portions of certain chapters in his writings. This erudite interest is not limited, however, to an encyclopedic exposition. The sporadic parenthetical references that abound in his works also prove the fundamental place that names occupy in his thinking. Thus in a discussion of music, we are told that the Greeks called music ethos 'character' to show its power over our way of life. ${ }^{23}$ A solecism evokes mention of the source of this figure in Soloi, a town of Cilicia, built by Solon. ${ }^{24}$ An allusion to aristocracy as a form of government leads to the remark that an Aristophanes character hated Scellius' son because his name was Aristocrat. ${ }^{25}$ The advocacy of travel reminds Le Vayer that the ancient Greeks were called Pelasgians (cf. above, p. 91) because they went from place to place like swans. ${ }^{26} \mathrm{~A}$ chapter on bastards includes the designation of Henry of Castile, known as The Cold after consenting to his Queen's becoming pregnant by Bernaldo de la Cueva. It also tells of a Spanish family, Hurtado, receiving its name from a child kidnaped (hurtado) just after birth. ${ }^{27}$ The subject of the memory is illustrated by Homer's naming Agamemnon thus and Artaxerxes, Memnon, due to their good

${ }^{23}$ Le Vayer, Discours sceptique sur la musique, in Euvres, IV.

24 Le Vayer, La Rhetorique du Prince, in EEvres, VI.

${ }^{25}$ Le Vayer, La Politique du Prince, in CEuvres, VII.

${ }^{26}$ Le Vayer, Des Petits Traitez, in Euvres, X, Lettre VI. On the name Pelasgi see note 22 a.

${ }^{27}$ Le Vayer, Des Petits Traitez, op.cit., Lettre XLIII. 
memory. ${ }^{28}$ Discussing news of the Court, Le Vayer digresses to remark that Ulysses was so named because he was born en route and was also called Outis for having large ears; ${ }^{29}$ the name Outis means of course 'No man' (see above, p. 91). In the midst of a plea for the aged, we learn that whereas in France people take the name of a town, in Brazil towns are named for people. ${ }^{30}$ Some remarks on geography attribute the misplacing of Mt. Ida on maps to the fact that the Greeks called any place covered with forests of high trees an Ida. ${ }^{31}$ A philosophical discourse on divine cults lists various names of the Devil: Arimanes in Persia, Manitou in Canada, $M a$ boya in the American Islands [sic], and Camate in the Cape Verde Islands. ${ }^{32} \mathrm{~A}$ review of the history of oracles includes, somewhat parenthetically, a reference to Strabo's discussion of the name of Daphne, called Phemonoe by Strabo himself, but by others Pythia from the Greek, signifying "to question." According to Pansanias, continues Le Vayer, her name was either Hierophile, containing the prediction of Ilium's burning, or Lamia, the daughter of Neptune. ${ }^{33}$ In a treatise on scholarly writing, Le Vayer notes that Minerva favored rest and vacations, and was therefore called the Goddess Vacuna by the Romans. ${ }^{34}$ A passage on bringing up children digresses to remark that Aegisthus was so named for having been nursed by a goat, a fact which made him capricious and fleetfooted..$^{35}$ Le Vayer, the pedagogue, tells of a teacher who had to give a dull pupil playmates, each called by a letter of the Greek alphabet, to encourage him to learn it. ${ }^{36}$ Writing on life and death, Le Vayer suddenly introduces the Nacrobians of Apollonia, so named for their longevity. ${ }^{37}$ The name Paris offers several quasiparenthetical references. In a Dialogue it is suggested that Paris might well be named Ticinum, as once was Pavia, for its admirable appearance. However, it is also stated that the poor treatment of foreigners warrants for Paris the name Epidamnum, "... quod

\footnotetext{
- 28 Le Vayer, op.cit., Lettre XLVI.

${ }^{29}$ Le Vayer, Des Petits Traitez, in ELuvres, XI, Lettre LXVI. A second reference to the name, Outis, in a later volume suggests that Ulysses' big ears made him a good listener to prophecies. See Dernières Homilies académiques, in Euvres, XV, $25^{\mathrm{e}}$ Homilie, p. 360.

so Le Vayer, Des Petits Traitez, in Euvres, XI, Lettre LXXVI.
${ }^{31}$ Ibid., Lettre LXXXIX. $\quad 32$ Ibid., Lettre CLI. $\quad{ }^{33}$ Ibid., Lettre CVI.
34 Ibid., Lettre CVII. $\quad{ }^{35}$ Op.cit., Euvres XII, Lettre CXXXI.

36 Le Vayer, op.cit. $\quad 37$ Le Vayer, op.cit.
} 
illuc nemo fere nisi damno suo diverteret" (because scarcely anyone will go there except he be damned). As the residence of princes and ministers, Paris might be called Melilot, 'City of Counsel,' a name a Florida tribe gave their capital. During this dialogue, the Seine is called the Chrysorrhoas. ${ }^{38}$ A disquisition on names calls forth the Persian name for chess; namely, Sedrents, 'A Hundred Cares,' or Schach (from Shah), the source of French "échec." 39 Criticizing the publication of certain contemporary books, Le Vayer compares them to Axilon in Asia, a name which Livy attributes to its total lack of the production of wood..$^{40}$ Finally, a comment on contemporary literary quarrels evokes the passing statement that Coion, an insulting name in France, is an honorable one in Bergamo. ${ }^{41}$

It is pertinent to mention that one type of book recommended by Le Vayer for a library limited to a hundred books is an encyclopedia of names. ${ }^{42}$ His own continual reliance on such a work for the material exposed in this article is obvious. However, his frequent allusions to names reflect a method of thought fundamental to his writings. As a sceptic, Le Vayer doubts the decisiveness of philosophical systems. He makes manifest his opposition to dogmatic systematization through a method used already by Montaigne and later brilliantly exploited in Voltaire's Essai sur les moeurs, which is simply a comparative study of world customs. Located deep within the roots of various cultural heritages, names comprise a telling illustration of the invalidity of definitive statements with regard to world-wide social practices.

Lehigh University

${ }^{38}$ Le Vayer, in Euvres, XIII, Dialogue IV, "Entre Tubertus Ocella et Xilinus." He would seem to be referring to the economic advantages of the Seine, as the word means 'gold-pouring' and was once applied to the elegant style in which John of Damascus wrote Greek.

${ }^{39}$ Le Vayer, Homilies académiques, in CEuvres, XIV, $4^{\mathrm{e}}$ Homilie.

40 Le Vayer, Observations diverses sur la composition, \& sur la lecture des livres, in Euvres, XV, 16.

${ }^{41}$ Le Vayer, op.cit., "Préface," p. 259.

42 Le Vayer, Des Petits Traitez, in Euvres, X, Lettre XIII. 